\title{
RADIOCAESIUM IN HONEY FROM KOŠICE AND PREŠOV REGIONS IN EASTERN SLOVAKIA
}

\author{
Beňová, K. ${ }^{1}$, Dvořák, P. ${ }^{2}$, Špalková, M. ${ }^{1}$ \\ ${ }^{1}$ Institute of biology, zoology and radiobiology \\ University of Veterinary Medicine and Pharmacy in Košice, Komenského 73, 04181 Košice, \\ Slovakia \\ ${ }^{2}$ Central workplace for the use of ionizing radiation, Institute of Gastronomy \\ Veterinary and Pharmaceutical University in Brno, Palackého 1-3, 61242 Brno, \\ Czechia \\ katarina.benova@uvlf.sk
}

\section{ABSTRACT}

The activity of radiocaesium was measured in 50 samples of blossom and honeydew honey obtained in the years 2017 and 2018 from beekeepers from various localities of Košice and Prešov regions, eastern Slovakia. The measurements were carried out by gamma spectrometry in Marinelli-type vessels of volume $450 \mathrm{ml}$ without any previous processing of samples. The activity of radiocaesium in honey samples were low, below the detection level of $0.2 \mathrm{~Bq} \cdot \mathrm{kg}^{-1}$ in the majority of samples, and was near the levels measured before the Chernobyl disaster. Higher values were detected in honeydew honey compared to the blossom honey. Consumption of honey from the regions presents no risk of exposure to ${ }^{137} \mathrm{Cs}$.

Key words: blossom honey; honeydew honey; radiocaesium; Slovakia

\section{INTRODUCTION}

Since the times of the most famous antique doctor and father of medicine Hippocrates, honey has been recommended as a miracle and universal medicine suitable for the treatment of many diseases [29]. It has had a valued place in traditional medicine for centuries. Honey has been reported to have an inhibitory effect on around 60 species of bacteria including aerobes, anaerobes, Gram-positives and Gram-negatives [19, 20]. In addition to antibacterial and antifungal effects, natural honey has demonstrated antiviral effects $[1,10]$. The mechanisms of antimicrobial activity of honey are different from antibiotics, which destroy the bacteria's cell wall or inhibit intracellular metabolic pathways. The antibacterial activity is related to four properties of honey. First, honey draws moisture out of the environment and thus dehydrates bacteria. The sugar content of honey is also high enough to hinder the growth of 
microbes, but the sugar content alone is not the sole reason for honey's antibacterial properties [27]. Second, the $\mathrm{pH}$ of honey is between 3.2 and 4.5, and this acidity is low enough to inhibit the growth of most microorganisms. Hydrogen peroxide produced by the glucose oxidase is the third and probably the most important antibacterial component, although some authors believe the non-peroxide activity to be more important. Lastly, several phytochemical factors for antibacterial activity have been identified in honey [1, 10]. It stimulates the central nervous system and human psychics, improves the quality of sleep, acts as a source of energy and supports digestion, facilitates the treatment of the liver, ulcerous diseases of the stomach and duodenum. Honey is also effective in healing of wounds, but the exact mechanism of this effect is yet to be elucidated [10]. Studies carried out on animals showed honey's effect against cardiovascular risk factors [31]. Honey also decreases venous blood pressure and inhibits oxidative stress, enhances detoxification of an organism, supports the immune system and increases performance in general [10].

Honey is classified as blossom honey (nectar of plants) or honeydew honey (secretions of living parts of plants or excretions of plant-sucking insects on the living parts of plants). Honeydew honey is generally characterised by higher values of electric conductivity, $\mathrm{pH}$, acidity and ash content, darker colour, higher oligosaccharides content and lower content of monosaccharides than the blossom honey. The antioxidant and antibacterial properties of honeydew honey are higher than those of most blossom honeys [22].

Honey is relatively free of adverse effects. Allergy to honey is rare, but there could be an allergic reaction to either pollen or bee proteins in honey. Theoretical risk of rise in blood glucose levels may always be there when applied to large open wound in diabetics [10].

Honeybees have been used as monitors of a variety of environmental contaminants, including trace metals, low level radioactivity and pesticides [14]. Due to their ability to act as unique environmental samplers of pollutants they can be intentionally placed into the regions with increased air pollution which is then reflected in the content of xenobiotics in bee bodies and their products, particularly in honey, propolis, and most frequently in pollen [14, 28].

Flower pollen is a good indicator of air contamination. By simply fitting a pollen trap to a honeybee hive, and measuring the radiocaesium content of the pollen species present, it is possible to produce models to give accurate and precise estimations of concentrations in leaves and flowers of plants within the forage area [18]. Because the beeswax is used to produce honeycomb cells, it also reflects the cumulated environmental pollution. In Austria they were able to detect in this way substances that have been banned for 13 years. On the contrary, honey is exceptionally protected by bees and thus it constitutes a pure product obtained also under worse conditions [30].

Contamination of the environment by artificial radionuclides occurred as a result of nuclear weapons testing in the fifties to sixties of the 20th century and the Chernobyl accident in 1986. I p a t y e $\mathrm{v}$ et al. [15] focused on the influence of this accident on the forest ecosystem in the period of 1986-1994. They observed that oak trees exhibited stronger ${ }^{137} \mathrm{Cs}$ absorption capacities than pine trees. Due to the time lapse and the character of the Chernobyl accident, of the artificial radionuclides only ${ }^{137} \mathrm{Cs}$ with physical halftime decay of 30.1 years were detected recently in the soil in Slovakia [16]. According to $\breve{S}$ a r o and Tolgy e s s y [24] caesium is the radionuclide which passes to the food chain due to surface contamination of soil and crops. Caesium is retained in the surface layer of soil and can be taken up partially by the roots of plants. It is its subsequent accumulation in plants that is the main subject of concern. The radiocaesium then enters the digestion tract through the food chain [5].

The aim of this study was to determine the activity of radiocaesium in individual samples of blossom and honeydew honey collected from various locations in eastern Slovakia and compare the maximum values with the maximum acceptable level specified by the relevant legislative provisions [6].

\section{MATERIALS AND METHODS}

Fifty samples of honey (42 blossom and 8 honeydew honey) were collected in the years 2017 and 2018 from the Prešov and Košice regions in eastern Slovakia. The samples were provided by honeybee keepers that participate actively in production of honey and honeybee products.

Gamma-ray spectrometric measurements were used for assaying gamma-ray emitting radionuclides. This measurement is based on the use of detectors of the semiconductor type that are used for qualitative analysis of energy of the ionizing radiation of certain radionuclide but also 
for quantitative analysis of the content of radionuclide in the sample based on emission of photons of specific energy. This method is suitable for measurement in environmental samples with low radioactivity. As it requires no preparation of the sample material, the measurements were carried out on the samples of honey that were not subjected to any previous processing.

The samples were transferred to Marinelli beakers with a volume of $450 \mathrm{ml}$ and the measurements were performed using a gamma spectrometer (Canberra) equipped with Ge detector (GC 4020 with $40 \%$ effectiveness and $1.8 \mathrm{keV}$ resolution) and DSA-LX analyser according to the manufacturer's instructions. All measurements were carried out at the Veterinary and Pharmaceutical University in Brno, Czech Republic. The presented relative standard uncertainties ua were determined according to JCGM 100:2008, 1st edn. [11].

\section{RESULTS AND DISCUSSION}

Of the 50 samples of honey, activities of ${ }^{137} \mathrm{CS}$ in 35 samples were below the detection limit of $0.2 \mathrm{~Bq} \cdot \mathrm{kg}^{-1}$. Table 1 shows the activities of ${ }^{137} \mathrm{Cs}$ measured in honey samples that exceeded this level $(n=15)$. Results are presented as Activity concentration \pm combined standard uncertainties ua [11].

The radioactivity level in all honeydew honey samples measured $(\mathrm{n}=8)$ exceeded $1.72 \mathrm{~Bq} \cdot \mathrm{kg}^{-1}$. The highest ${ }^{137} \mathrm{Cs}$ activity was detected in honeydew honey $\left(2.33 \pm 0.05 \mathrm{~Bq} \cdot \mathrm{kg}^{-1}\right)$ that originated from the location Branisko. The highest ${ }^{137} \mathrm{Cs}$ activity in blossom honey was detected in rape honey from Nižná Šebastová.

Examination of honeys from industrially polluted regions did not show the presence of pollutants which, however, was not true for the bodies of bees nor the bee poison where various contaminants were found. This indicated that bees are able to produce pure honey, even from polluted sources, and thus function as a biological filter retaining the contaminants and not passing them to this product. Despite that, trace amounts of pesticides were detected in honeys that the bees were not able to remove by their gastrointestinal tract [7].

Nectar (blossom) honeys are produced during the spring and the early summer, normally over short periods of time. The nectar secretion pattern is very abundant and fast, and the blossom honey production is completed quickly. Production of honeydew honeys takes longer as it probably begins as blossom honey early in spring but is mixed with honeydew secretions toward the end of summer [9]. Because of the delayed collection of honeydew honey, this honey is always a little more contaminated than the blossom honey. This was reflected also in our results. Additional sources of contamination may be polluted water or artificial fertilizers.

The use of bees as indicators is important particularly in big cities and around highways as bees obtain nectar and pollen from plants that take up minerals from soil and thus serve as indicators of heavy metals. Bees also belong to the most accurate indicators of air quality because the trapped pollen may be successfully analysed. The more accurate assessment of environmental pollution of a relevant region requires presence of several bee colonies.

One should also mention the fact that the movement of xenobiotics throughout the plant is not so intensive, and after the pollutants are taken up by roots they accumulate for some time in the root system before they pass to the

Table 1. Activities of ${ }^{137} \mathrm{Cs}$ in the samples that exceeded the detection limit of $0.2 \mathrm{~Bq} \cdot \mathrm{kg}^{-1}$

\begin{tabular}{llc}
\hline Type of honey & Location & $\begin{array}{c}\text { Activity concentration } \\
{\left[\text { Bq.kg }{ }^{-1}\right] \pm \text { combined }} \\
\text { standard uncertainties } \\
\text { ua [11] }\end{array}$ \\
\hline Honeydew & Branisko & $2.33 \pm 0.05$ \\
Honeydew & Podhradík & $2.05 \pm 0.01$ \\
Honeydew & Lubotín & $1.82 \pm 0.02$ \\
Honeydew & Šindliar & $1.91 \pm 0.04$ \\
Honeydew & Helcmanovce & $2.09 \pm 0.14$ \\
Honeydew & Košice & $1.73 \pm 0.03$ \\
Honeydew & Kavečany & $1.72 \pm 0.11$ \\
Honeydew & Krompachy & $2.26 \pm 0.13$ \\
Blossom (rape) & Šalgovík & $0.21 \pm 0.03$ \\
Blossom (rape) & Nižná Šebastová & $0.75 \pm 0.02$ \\
Blossom (rape) & Košice & $0.27 \pm 0.05$ \\
Blossom (buckwheat) & Kendice & $0.33 \pm 0.02$ \\
Blossom (linden) & Lipovec & $0.52 \pm 0.03$ \\
Blossom (sunflower) & Lačnov & $0.27 \pm 0.02$ \\
Blossom (meadow) & Malý Šariš & $0.23 \pm 0.01$ \\
\hline
\end{tabular}


honeydew or nectar. This indicates that it is more relevant to determine the real content of pollutants in the air than in the soil [23].

Franić and Branica [12] conducted long-term investigations of ${ }^{134} \mathrm{Cs}$ and ${ }^{137} \mathrm{Cs}$ activity concentrations in multifloral and chestnut honey sampled in northwest Croatia. For both radionuclides, the activity concentrations peaked in May 1986, decreasing exponentially until the mid-1990s, when they fell under the detection limit for both radionuclides. After the Fukushima-Daiichi accident in 2011, the presence of both radionuclides in honey was detected once again. The observed ${ }^{134} \mathrm{Cs} /{ }^{137} \mathrm{Cs}$ activity ratio in honey was similar to the ratio found in other environmental samples. The estimated collective effective doses for the Croatian population incurred by honey consumption indicated that honey was not a critical pathway for the transfer of ${ }^{134} \mathrm{Cs}$ and ${ }^{137} \mathrm{Cs}$ from fallout to humans [12].

There were large variations in the radionuclide deposition levels. Of the artificial radionuclides associated with the Chernobyl accident, only ${ }^{137} \mathrm{Cs}$ occurred recently in the soil in Slovakia [16]. This radionuclide rapidly integrated into the biological cycle, similar as potassium [13].

The proportion of ${ }^{137} \mathrm{Cs}$ available to plants can vary in soils with high content of minerals depending on many factors. Under certain conditions, it can even increase with depth [25]. Through consumption of plants it can pass to the muscles of animals. In the period of $1998-2008,{ }^{137} \mathrm{Cs}$ activity in the muscles from wild boars hunted in the Ravensburg district (southern Germany) varied from less than 5 up to 8266 Bq. $\mathrm{kg}^{-1}$ in dependence on season, atmospheric conditions and other factors [26]. After a gradual decrease of ${ }^{137} \mathrm{Cs}$ in game meat in the nineties in north-eastern Moravia, its levels unexpectedly increased after floods and exceeded the acceptable limit of 600 Bq. $\mathrm{kg}^{-1}$ [17]. Despite such high levels in the surrounding states, samples of wild boar meat did not even approach the acceptable level of ${ }^{137} \mathrm{Cs}[2,16]$.

Before the Chernobyl accident that occurred on 26th April 1986, the activity of ${ }^{137} \mathrm{Cs}$ in honey varied around $2 \mathrm{~Bq} \cdot \mathrm{kg}^{-1}$ as a result of nuclear weapons tests [8]. B u $\mathrm{z} \mathrm{l}$ et al. [4] started with measurements of the activity of radionuclides in honey and pollen in the region of Munich in week intervals up to August 1986. At the beginning of May, the specific activity of ${ }^{137} \mathrm{Cs}$ exceeded $600 \mathrm{~Bq} \cdot \mathrm{kg}^{-1}$ but in the course of May it decreased to $200 \mathrm{~Bq} \cdot \mathrm{kg}^{-1}$. The activity of ${ }^{137} \mathrm{Cs}$ was higher in pollen in comparison with honey. $\mathrm{B}$ o r a w s k a et al. [3] determined radioactivity of honey
12 years following Chernobyl. The activity of 39 samples ranged between 0.5 and $46.3 \mathrm{~Bq} \cdot \mathrm{kg}^{-1}$. The highest mean level (24.3 Bq. $\left.\mathrm{kg}^{-1}\right)$ was measured in heather honey and the lowest (0.6 Bq. $\left.\mathrm{kg}^{-1}\right)$ in blossom honey. Between June 2001 and December 2004, the ${ }^{137}$ Cs activity was investigated in a total of 336 samples of different varieties of honey from the Liguria region of Northern Italy. The purpose of this study was to define (a) residual radioactive contamination following the Chernobyl accident and ${ }^{137} \mathrm{Cs}$ long-term decline, (b) correlation between ${ }^{137} \mathrm{Cs}$ activity and different honey varieties, and (c) correlation between ${ }^{137} \mathrm{Cs}$ activity and the prevailing geomorphological configuration in the collection areas. The results were compared according to the place of the nectar collection and the type of honey. Significantly higher concentrations of ${ }^{137} \mathrm{Cs}$ were measured in the valley of the river Stura (mean level $8.45 \mathrm{~Bq} \cdot \mathrm{kg}^{-1}$ ). In this region the heaviest rains occurred when the post-accident radioactive cloud passed over this area. The mean ${ }^{137} \mathrm{Cs}$ specific activity was $4.33 \pm 5.04$ S.D. Bq. $\mathrm{kg}^{-1}$. The levels of ${ }^{137} \mathrm{Cs}$ in chestnut honey were significantly higher than in other types of honey which was ascribed to the extensive, superficial and deep, root apparatus of the tree. Honey samples from acidic argillite soils, which withhold radionuclides after deposition and slowly release them to plants, also showed higher ${ }^{137} \mathrm{Cs}$ activity. The authors used the data obtained in the study to calculate the half-life decay of ${ }^{137} \mathrm{Cs}$ in honey. They obtained the following results: acacia honey 437 days ( 1.199 years); chestnut honey 577 days ( 1.58 years) and honeydew honey 394 days (1.08 years) [21].

Comparison of our results showed higher concentration of radioactive caesium in samples of honeydew honey in comparison with blossom honey. Similar results were presented by B o r a w s k a et al. [3]. In the case of raw materials, semi-finished products and products originating exclusively or partially from the forest ecosystem one should consider that potentially increased levels of radiocaesium may occur even without changes in the current radiation situation in Slovakia. The activities of ${ }^{137} \mathrm{Cs}$ determined in the samples of honey examined in our study correspond to the activities measure before the Chernobyl accident.

\section{CONCLUSIONS}

The activities of radiocaesium in honey samples determined in this study were very low and were far below 
the acceptable radioactivity limit in food set by legislation for persistent contamination after the Chernobyl accident $\left(600 \mathrm{~Bq} \cdot \mathrm{kg}^{-1}\right)$. In the majority of samples the radiocaesium activity was below the detection limit of $0.2 \mathrm{~Bq} \cdot \mathrm{kg}^{-1}$. This implies that consumption of honey originating from the investigated Slovak regions poses no risk to the human health resulting from post-Chernobyl radiocaesium contamination.

\section{REFERENCES}

1. Al-Waili, N. S. Haq, A., 2004: Effect of honey on antibody production against thymus-dependent and thymus-independent antigens in primary and secondary immune responses. J. Med. Food, 7, 491-494.

2. Beňová, K., Dvořák, P., Tomko, M., Falis, M., 2016: Artificial environmental radionuclides in Europe and methods of lowering their foodstuff contamination-a review. Acta Veterinaria Brno, 85, 1, 105-112. DOI: 10.2754/avb201685010105.

3. Borawska, M. H., Kapala, J., Hukalovicz, K., Markiewicz, R., 2000: Radioactivity of honeybee honey. Bull. Environ. Contam. Toxicol., 64, 5, 617-621.

4. Bunzl, K., Krocke, W., Vorwohl, G., 1988: Transfer of Chernobyl-derived ${ }^{134} \mathrm{Cs},{ }^{137} \mathrm{Cs}, 131 \mathrm{I}$ and $103 \mathrm{Ru}$ from flowers to honey and pollen. Journal of Environmental Radioactivity, 6 , $3,261-269$.

5. Černegová, L., Beňová, K., 2015: Contamination with radionuclides in the district Turčianske Teplice in Slovakia. Folia Veterinaria, 59, 2, 118-120.

6. Council Regulation 616/2000/EC, 2000: Council Regulation of 20th March 2000 amending Regulation (EEC) No 737/90 on the conditions governing imports of agricultural products originating in third countries following the accident at the Chernobyl nuclear power station. Official Journal of the European Communities, L75/1.

7. Crane, E., 1990: Bees and Beekeeping: Science Practice and World Resources. 1st edn., Cornell University Press, Ithaca, NY, 640 pp.

8. Djuric, G., Popovic, D., Todorovic, D., Slovka, J., Mihaljev, Z., 1996: Natural and fallout radionuclides in different types of honey. J. Environ. Biol., 17, 4, 339-343.

9. Escuredo, O., Fernández-Gonzáles, M., Seijo, M. C., 2012: Differentiation of blossom honey and honeydew honey from Northwest Spain. Agriculture, 2, 25-37. DOI: 10.3390/agriculture2010025.
10. Eteraf-Oskouei, T., Najafi, M., 2013: Traditional and modern uses of natural honey in human diseases: A Review. Iran J. Basic Med. Sci., 16, 6, 731-742.

11. Evaluation of Measurement Data-Guide to the Expression of Uncertainty in Measurement, 2008: JCGM, 100, 2008, 1st edn., GUM 1995 with minor corrections, 134 pp.

12. Franić, Z., Branica, G., 2019: Long-term investigations of ${ }^{134} \mathrm{Cs}$ and ${ }^{137} \mathrm{Cs}$ activity concentrations in honey from Croatia. Bull. Environ. Contam. Toxicol., 102, 4, 462-467. DOI: 10. 1007/s00128-019-02571-8

13. Gadd, G. M., 1996: Influence of microorganisms on the environmental fate of radionuclides, Endeavour, 20, 1996, $150-156$.

14. Hinca, R., Petriska, M., 2017: Radiological monitoring of beehives and honey for ground radioactive pollution assessment. In Proceedings Vajda, J., Jamnický I.: APCOM 2017. Bratislava, Spektrum, STU, 178-180.

15. Ipatyev, V., Bulavik, I., Baginsky, V., Goncharenko, G., Dvornik, A., 1999: Forest and Chernobyl. Forest ecosystems after the Chernobyl nuclear power plant accident: 1986 1994. Journal of Environmental Radioactivity, 42, 9-38.

16. Kanta, M., Beňová, K., 2018: Monitoring of ${ }^{137} \mathrm{Cs}$ and $40 \mathrm{~K}$ in the Levice district, southern Slovakia. Folia Veterinaria, 62, 1, 38-43. DOI: 10.2478/fv-2018-0006.

17. Latini, T., 2011: Occurrence of radioactivity in wild boars (In Czech). Maso, 5, 2011, 24-26.

18. McGee, E. J., McGarry, A., 1994: The uses of bioindicators in radionuclide contamination assessment. In Soil-Plant Relationships Proceedings of the 24th Annual ESNA/IUR Meeting, Sept. 12-16, Varna, Bulgaria, 301 pp.

19. Molan, P. C., 1992: The antibacterial activity of honey. 1. The nature of antibacterial activity. BeeWorld, 73, 5-28.

20. Olaitan, P. B., Adeleke, E. O., Ola, O. I., 2007: Honey: a reservoir for microorganisms and an inhibitory agent for microbes. Afr. Health Sci., 7, 159-165.

21. Panatto, D., Gasparini, R., Lai, P., Rovatti, P., Gallelli, G., 2007: Long-term decline of ${ }^{137} \mathrm{Cs}$ concentration in honey in the second decade after the Chernobyl accident. Science of the Total Environment, 382, 1, 147-152.

22. Pita-Calvo, C., Vázques, M., 2017: Differences between honeydew and blossom honeys: A review. Trends in Food Science and Technology, 59, 79-87. DOI: 10.1016/j.tifs.2016. 11.015 .

23. Přidal, A., 2005: Bee Products (In Czech). Reprint with adjustments. Mendel's Agricultural and Forestry University in Brno. 102 pp. 
24. Šaro, Š., Tolgyessi, J., 1985: Radioactivity of the Environment (In Slovak). Alfa, Bratislava, 303 pp.

25. Schimmack, W, Bunzi, K., 1996: Mobility of Chernobylderived radiocaesium in the soil. In Proceedings of the International Symposium on Radioecology, Vienna. In Mitteilungen Ost. Bodenkundlichen Ges., 53, 118.

26. Semizhon, T., Putyrskaya, V., Zibold, G., Klemt, E., 2009: Time-dependency of the ${ }^{137} \mathrm{Cs}$ contamination of wild boar from a region in Southern Germany in the years 1998 to 2008. Journal of Environmental Radioactivity, 100, 11, 988-992.

27. Simon, A., Traynor, K., Santos, K., Blaser, G., Bode, U., Molan, P., 2007: Medical honey for wound care-still the 'latest resort'? eCAM, 1-9.

28. Smith, K. E., Weis, D., Amini, M., Shiel, A. E., Lai, V., W.-M., Gordon, K., 2019: Honey as a biomonitor for a changing world. Nature Sustainability, 2019, 2, 3, 223. DOI: 10.1038/ s41893-019-0243-0.
29. Vorlova, L., 2002: Honey: Comprehensive Analysis (In Czech), 1st edn., Veterinary and Pharmaceutical University in Brno, Faculty of Veterinary Hygiene and Ecology, 62 pp.

30. Witkiewicz, W., Romaniuk, K., Witkiewicz, A., 2000: Honey-one of the purest environmental products. In Proceedings of the 1st European Scientific Apicultural Conference, Pulawy, Poland, $91 \mathrm{pp}$.

31. Yaghoobi, N., Al-Waili, N., Ghayour-Mobarhan, M., Parizadeh, S. M. R., Abasalti, Z., Yaghoobi, Z., et al., 2008: Natural honey and cardiovascular risk factors; effects on blood glucose, cholesterol, triacylglycerole, CRP and body weight compared with sucrose. Sci. World J., 8, 463-469. DOI: 10.1100/ tsw.2008.64.

Received June 14, 2019

Accepted September 23, 2019 